\title{
Sensitive NMR Method for Detecting Carbohydrate Influx into Competing Chemocatalytic Pathways
}

Elliot, Samuel Gilbert; Jessen, Bo Michael; Taarning, Esben; Madsen, Robert; Meier, Sebastian

Published in:

Analyst

Link to article, DOI:

10.1039/d0an00555j

Publication date:

2020

Document Version

Peer reviewed version

Link back to DTU Orbit

Citation (APA):

Elliot, S. G., Jessen, B. M., Taarning, E., Madsen, R., \& Meier, S. (2020). Sensitive NMR Method for Detecting Carbohydrate Influx into Competing Chemocatalytic Pathways. Analyst, 145, 4427-4431.

https://doi.org/10.1039/d0an00555j

\section{General rights}

Copyright and moral rights for the publications made accessible in the public portal are retained by the authors and/or other copyright owners and it is a condition of accessing publications that users recognise and abide by the legal requirements associated with these rights.

- Users may download and print one copy of any publication from the public portal for the purpose of private study or research.

- You may not further distribute the material or use it for any profit-making activity or commercial gain

- You may freely distribute the URL identifying the publication in the public portal 


\title{
Sensitive NMR Method for Detecting Carbohydrate Influx into Competing Chemocatalytic Pathways
}

abellReceived 00th January 20xx

\author{
Samuel G. Elliot, ${ }^{\text {a }}$ Bo Jessen, ${ }^{a \dagger}$ Esben Taarning, ${ }^{\mathrm{b}}$ Robert Madsen, ${ }^{\mathrm{a}}$ and Sebastian Meier ${ }^{\mathrm{a}}{ }^{*}$
}

Accepted 00th January 20xx

DOI: $10.1039 / x 0 \times x 00000 x$

Reaction pathways are often tracked with stable isotopes in order to determine the provenance of products in the pathway and to deduce mechanistic information. NMR spectroscopy can provide direct insight into the specific labelling position of the stable isotope. We suggest a simple assay that allows rapid quantitative measurements of isotope distributions in biomass-derived products using commercially available carbohydrate substrates and routine instrumentation. In the assay, biomass-derived products in post reaction material are quantitatively reduced with $\mathrm{NaBH}_{4}$ to install hydrogens at each carbon site in the product. In this manner, the detection of ${ }^{13} \mathrm{C}$ and ${ }^{12} \mathrm{C}$ sites becomes possible in multiplets of the sensitive $2 \mathrm{D}^{1} \mathrm{H}-{ }^{1} \mathrm{H}$ TOCSY experiment. The approach detects the usage of competing upstream reactions from isotope patterns in chemically identical reaction products. Changing influx into SnBeta-catalysed carbohydrate conversion reactions in the absence and in the presence of $\mathrm{K}^{+}$was quantitatively assessed, showing how the presence of $\mathrm{K}^{+}$alters the intial reactions towards methyl lactate.

Heterogeneous catalysts bear considerable promise for the sustainable conversion of renewable substrates to fuels and materials. ${ }^{1-4}$ An important question in the development and optimization of suitable catalysts is the selectivity of the desired processes, including the influence of reaction conditions or additives on selectivity. ${ }^{5-8}$ Direct studies of catalyst-substrate complexes have remained difficult. The short-lived nature of the complexes and the difficulty in rapidly obtaining sufficient chemical detail has often proven too challenging, especially in heterogeneously catalysed conversion. Catalytic mechanisms can be often inferred, however, by using isotope-enriched substrates to measure kinetic effects or isotope distributions in the products. ${ }^{9-15}$

\footnotetext{
a. Department of Chemistry, Technical University of Denmark, Kemitorvet, Bygning 207, 2800 Kgs. Lyngby, Denmark

${ }^{b .}$ Haldor Topsøe A/S, Haldor Topsøes Allé 1, 2800 Kgs. Lyngby, Denmark tEqual contribution.

Electronic Supplementary Information (ESI) available: [details of any supplementary information available should be included here]. See DOI: 10.1039/x0xx00000x
}

Among the heterogeneous catalysts employed for carbohydrate conversion, the zeotype Sn-Beta has attracted considerable attention. Sn-Beta is able to convert carbohydrates to prospective polymer building blocks and precursors. ${ }^{16-20}$ The widely abundant glucose, fructose and sucrose substrates can be converted to high yields of methyl lactate, especially in the presence of alkali ions at amounts comparable to the number of active sites. ${ }^{16,21,22}$ Considerable strides have therefore been made towards understanding SnBeta active site structures and functions, both in the absence and in the presence of alkali ion modification. ${ }^{23-30}$

Insight into the pathway usage under different conditions is a prerequisite to understand substrate-catalyst interaction, and to rationally optimize substrate influx into desired pathways. Such insight can become accessible by tracking isotope distributions either by mass spectrometry ${ }^{31}$ or by NMR spectroscopy. ${ }^{10,31}$ NMR spectroscopy permits direct insights into the specific labelling positions of the stable isotope. Thus, isotope distributions in methyl lactate deriving from $\left[1-{ }^{13} \mathrm{C}\right]$ xylose have previously shown that the substrate remains coordinated to the active site and does not react through a symmetric dihydroxyacetone form. ${ }^{32}$ In consequence, methyl lactate gets formed with ${ }^{13} \mathrm{C}$ enrichment predominantly at the C3 position. A challenge for the routine application of isotope tracking methods is that NMR spectroscopic measurements of ${ }^{13} \mathrm{C}$ isotope distributions through quantitative $1 \mathrm{D}{ }^{13} \mathrm{C} N M R$ (qNMR) is slow and insensitive, especially for small molecules with long- $T_{1}$ carbon atoms such as methyl lactate with its quaternary ester carbon. As an added grave disadvantage, the abundance of NMR silent ${ }^{12} \mathrm{C}$ sites is not accessible from quantitative $1 \mathrm{D}{ }^{13} \mathrm{C}$ NMR.

Here, we suggest a simple assay that provides rapid quantitative insight into isotope distributions of biomassderived products. Commercially available carbohydrate substrates and routine detection instruments can be used. The approach installs protons at the $\mathrm{C} 1$ position of methyl lactate through reduction with $\mathrm{NaBH}_{4}{ }^{33-35}$ prior to the indirect detection of ${ }^{13} \mathrm{C}$ and ${ }^{12} \mathrm{C}$ sites in multiplets of the sensitive $2 \mathrm{D}$ 

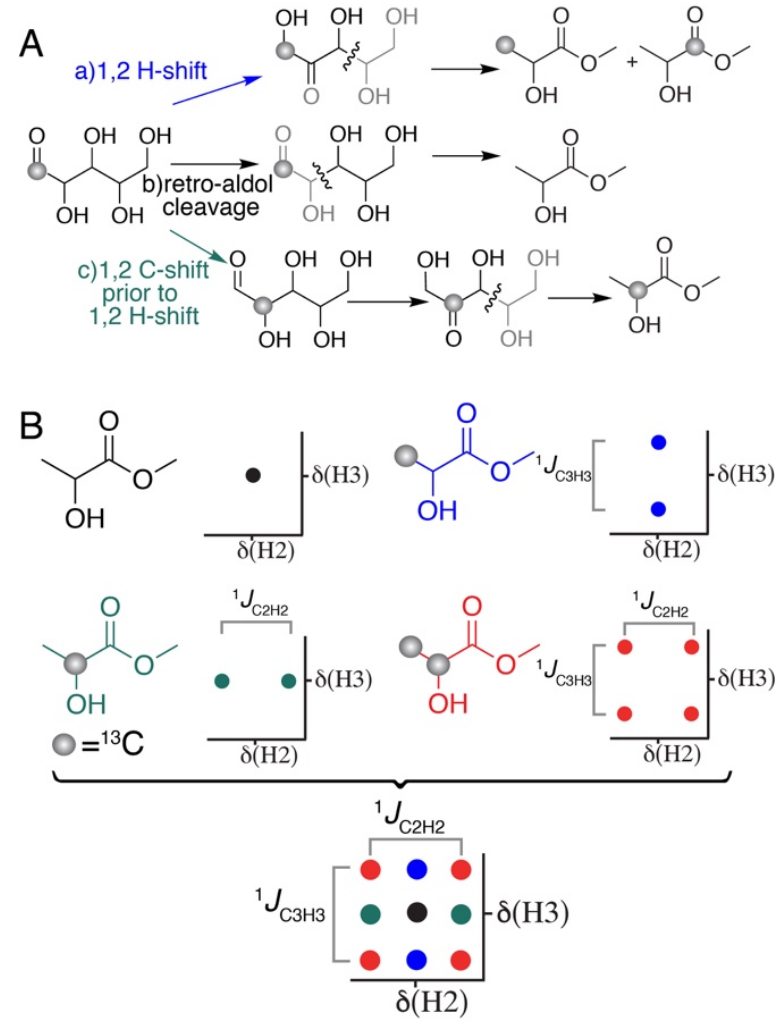

Scheme 1. (A) Schematic overview of $\left[1-{ }^{13} \mathrm{C}\right] x y$ lose conversion to various methyl lactate isotopomers by Sn-Beta catalysis in methanol at $160^{\circ} \mathrm{C}$. (B) Depiction of left) and the corresponding ${ }^{-1}{ }^{-}$TOCSY crOss-peak structures on the right.

${ }^{1} \mathrm{H}-{ }^{1} \mathrm{H}$ TOCSY experiment as schematically depicted in Scheme 1. ${ }^{10,12,36,37}$ This Scheme depicts that a cross signal between two different hydrogens can show four different fine structures, depending on the presence of ${ }^{13} \mathrm{C}$ directly bonded to either, both or none of the hydrogens. The experimentally observed signal is a weighted average of these four forms.

The described methodology was used to inspect the upstream reaction selectivity of the Sn-Beta-xylose complex in the presence and in the absence of alkali ions, where possible initial reactions towards methyl lactate may include 1,2intramolecular hydride shift (1,2-HS), 1,2-intramolecular carbon shift $(1,2-\mathrm{CS})$ or retro-aldol cleavage (Scheme 1). Use of $\left[1-{ }^{13} \mathrm{C}\right]$ xylose as the substrate results in an asymmetric retro-aldol cleavage that reveals, if methyl lactate in an unpurified reaction mixture derives from the aldose or from the ketose form. While other products such as longer alpha-hydroxy acids can be formed as byproducts, the methyl lactate product has been obtained at highest yield and arguably has attracted most commercial interest in this reaction. The $\left[1-{ }^{13} \mathrm{C}\right]$ xylose substrate (36 mg) was converted for five minutes at $160{ }^{\circ} \mathrm{C}$ by Sn-Beta (hydrothermally synthesized with $\mathrm{Si} / \mathrm{Sn}=20018 \mathrm{mg}$ ) in methanol using a microwave reactor, as previously described. ${ }^{32}$ In order to account for the population of methyl lactate without ${ }^{13} \mathrm{C}$, isotope-labelling was detected using a ${ }^{1} \mathrm{H}-{ }^{1} \mathrm{H}$ TOCSY spectrum. A representative cross-peak between the protons in the methyl and alcohol group of methyl lactate in post reaction material is shown in Fig. 1.

The cross-peak distinguishes between the absence of ${ }^{13} \mathrm{C}$

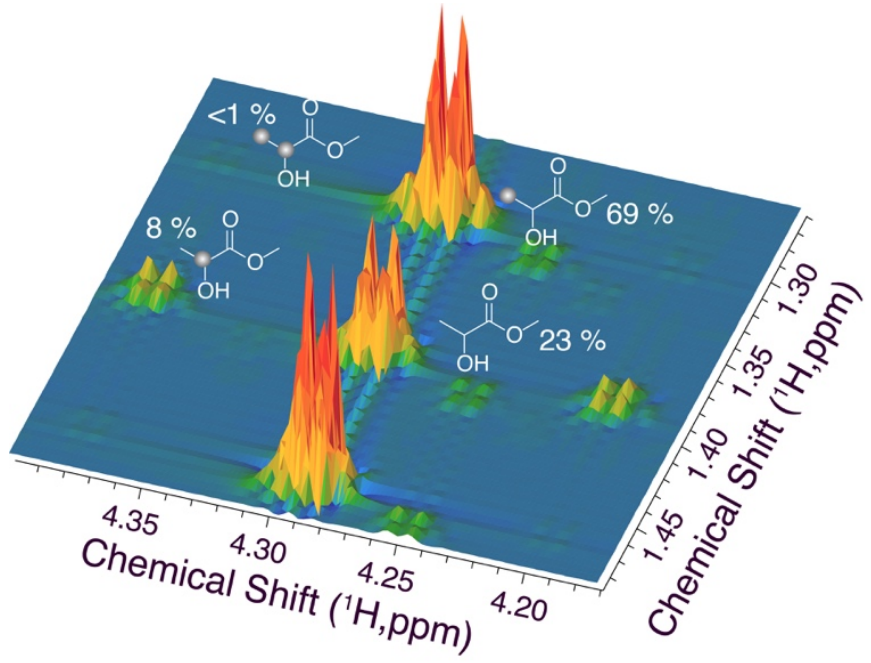

Fig. 1. ${ }^{1}{ }^{H}-1$ H TOCSY cross-peak between $\mathrm{H} 2$ and $\mathrm{H} 3$ in methyl lactate deriving from Sn-Beta catalysed conversion of [1- C xylose]. Reaction conditions: D-[1- C] $(5 \mathrm{mg})$, which were heated to $160^{\circ} \mathrm{C}$ ' for $5 \mathrm{~min}$.

label, presence of ${ }^{13} \mathrm{C}$ labelling at the $\mathrm{C} 2$ position only, at the $\mathrm{C} 3$ position only, or both at the $\mathrm{C} 2$ and the $\mathrm{C} 3$ position. Relative signal areas show that the majority of methyl lactate was ${ }^{13} \mathrm{C}$ labelled at the $\mathrm{C} 3$ position. A smaller prevalence was found of the isotopic form (isotopologue) without ${ }^{13} \mathrm{C}$ at either position or with ${ }^{13} \mathrm{C}$ labelling at $\mathrm{C} 2$ (see fractions in Figure 1). Double labelling at the $\mathrm{C} 2$ and $\mathrm{C} 3$ positions was negligible, as no intermolecular reaction occurred that channelled ${ }^{13} \mathrm{C}$ atoms from two substrate molecules into one methyl lactate product molecule.

The high abundance of ${ }^{13} \mathrm{C}$ labelling at the $\mathrm{C} 3$ position was consistent with previous observations indicating a concerted mechanism converting the $\mathrm{C} 1$ site in the carbohydrate substrate to the C3 site in methyl lactate, with minor scrambling to the C2 position due to $1,2-\mathrm{CS}^{32}$ Relative amounts of isotopic forms as determined from indirect observation through ${ }^{1} \mathrm{H}-{ }^{1} \mathrm{H}$ TOCSY cross-peaks were subsequently compared with quantifications from less sensitive and more time-consuming quantitative ${ }^{13} \mathrm{C}$ NMR experiments. Quantitative ${ }^{13} \mathrm{C} N M R$ experiments were obtained with an inter-scan relaxation delay of one minute using inverse-gated decoupling in the ${ }^{13} \mathrm{C}$ NMR spectrum of 130 min experiment time. This quantitative ${ }^{13} \mathrm{C} N M R$ assay has previously been validated gravimetrically. ${ }^{38}$ The correlation between indirect and direct measurements of isotopologue abundance is shown in Fig. 2. Determinations through ${ }^{1} \mathrm{H}-{ }^{1} \mathrm{H}$ TOCSY cross-peaks and through quantitative ${ }^{13} \mathrm{C}$ data yielded a Pearson correlation coefficient above 0.99. TOCSY determinations may further be improved by accounting for possible different relaxation behaviour in different isotopomers and isotopologues (Fig. S2, S3). ${ }^{11}$ The ${ }^{1} \mathrm{H}-{ }^{1} \mathrm{H}$ TOCSY approach permits the reliable isotopic analysis of less than 90 nanomole analyte in the NMR sample on an $800 \mathrm{MHz}$ instrument equipped with a $\mathrm{TCl}$ cryoprobe and of sub-micromole amounts on a standard $400 \mathrm{MHz}$ instrument within 10 minutes (Fig. S1, ESI).

Quantitative ${ }^{13} \mathrm{C}$ spectra and indirect observation in ${ }^{1} \mathrm{H}-{ }^{1} \mathrm{H}$ TOCSY cross-peaks provide complementary, but incomplete 
information. The 1D ${ }^{13} \mathrm{C}$ spectra detect quaternary carbon positions but do not contain information on NMR-silent ${ }^{12} \mathrm{C}$ sites. The ${ }^{1} \mathrm{H}-{ }^{1} \mathrm{H}$ TOCSY cross-peaks report on ${ }^{12} \mathrm{C}$ sites attached to $\mathrm{CH}$ groups, but do not monitor quaternary carbons. An approach to combine the sensitivity and information content of ${ }^{1} \mathrm{H}-{ }^{1} \mathrm{H}$ TOCSY with the ability to detect quaternary sites was therefore sought. To this end, hydrogen was installed at the C1 position of methyl lactate. To this end, a direct reduction of the post-reaction material was conducted with $\mathrm{NaBH}_{4}$ in the presence of catalytic amounts of sodium methoxide at room temperature. In basic solution, this approach predominantly formed borate esters of the 1,2 diol species formed by reduction of methyl lactate (Fig. $3 \mathrm{~A}$ and Fig. S3, ESI). NMR spectroscopy of the post-reaction material validates the nearcomplete conversion of the methyl lactate ester group (Fig. 3B). This approach leaves olefinic positions in byproducts intact (Fig. S4 and S5, ESI), ${ }^{35}$ while reducing ester groups by hydrogenation The conversion transforms methyl lactate to a product that

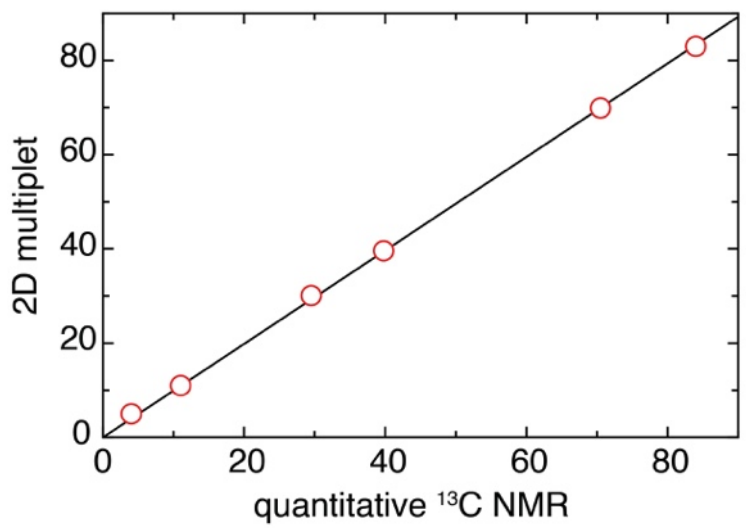

Fig. 2. Correlation between isotope distributions determined with quantitative ${ }^{13} \mathrm{C}$ and with ${ }^{1} \mathrm{H}-\mathrm{H}$ TOCSY multiplet structures, yielding a correlation coefficient of $\mathrm{Q}>0.99$. A line with a slope of 1 is shown as a guide to the eye.

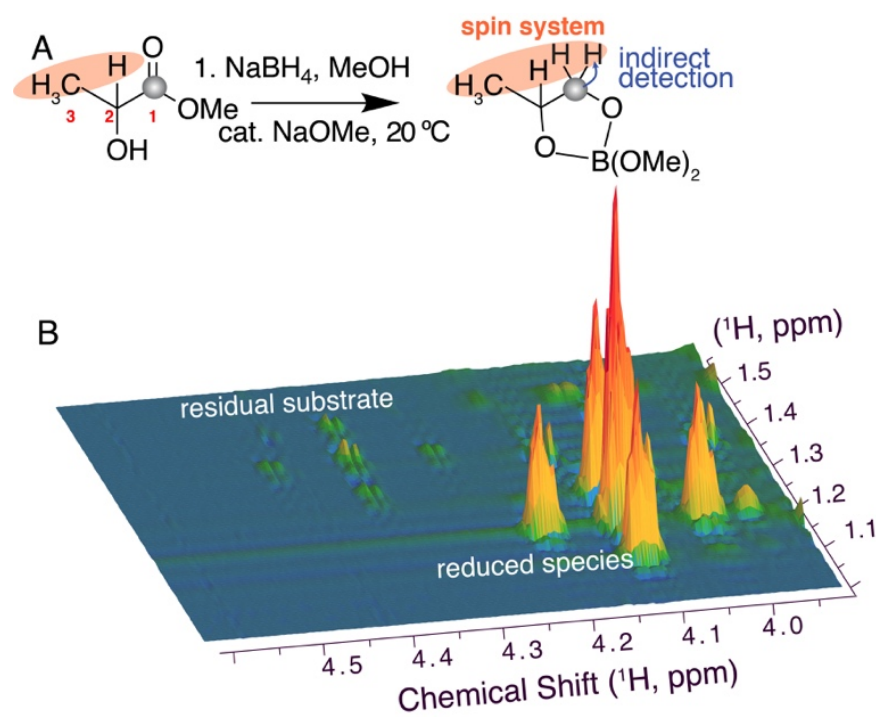

Fig. 3. (A) Reaction used to install protons at the $\mathrm{C} 1$ position of methyl lactate for detecting isotope distributions from $\mathrm{H}^{1} \mathrm{H}$ TOCSY cross-peaks also for the quaternary $\mathrm{C} 1$ site in methyl lactate (the reaction procedure is detailed in the ESI). product as shown for the cross-peaks between $\mathrm{H} 2$ and $\mathrm{H} 3$ in methyl lactate.

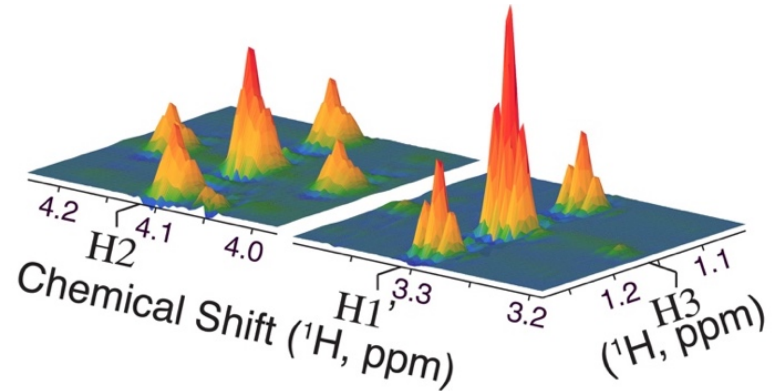

Fig. 4. ${ }^{1}{ }^{-1}-{ }^{1} \mathrm{H}$ TOCSY cross-peak for the methyl lactate signal deriving from $\mathrm{Sn}$-Beta catalysed conversion of $\left[1-{ }^{-3} \mathrm{C}\right]$ xylose, subject to reduction of the $\mathrm{C} 1$ positions as cate in the presence of $0.5 \mathrm{mM} \mathrm{K}_{2} \mathrm{CO}_{3}$.

permits the quantification of ${ }^{13} \mathrm{C}$ at all sites through ${ }^{1} \mathrm{H}$-based detection $\left({ }^{1} \mathrm{H}-{ }^{1} \mathrm{H}\right.$ TOCSY).

TOCSY cross-peaks resulting from methyl lactate after its reduction are shown in Fig 4, allowing to determine ${ }^{12} \mathrm{C}$ and ${ }^{13} \mathrm{C}$ populations in methyl lactate. The cross-peak between $\mathrm{H} 3$ and $\mathrm{H} 1$ protons shows that the $\mathrm{C} 1$ position is less enriched in ${ }^{13} \mathrm{C}$ compared to the $\mathrm{C} 2$ and $\mathrm{C} 3$ positions, as little splitting by a onebond coupling is observed in the $\mathrm{H} 1$ dimension of the cross peak. This observation is consistent with previous interpretations arguing against a free symmetric substrate as an on-pathway intermediate towards methyl lactate.

The novel assay was used herein to gain insight into the isotope redistribution upon changing reaction selectivity in the absence and in the presence of $0.5 \mathrm{mM} \mathrm{K}_{2} \mathrm{CO}_{3}$ in the reaction mixture. Alkali ions have previously been found to affect $\mathrm{Sn}$ Beta action on carbohydrates, favouring 1,2-CS over 1,2-HS near 80-100 ${ }^{\circ} \mathrm{C}^{7,}{ }^{39}$ and retro-aldol cleavage over dehydration reactions at $160{ }^{\circ} \mathrm{C} .{ }^{21}$ Populations of methyl lactate isotopologues were thus quantified with the ${ }^{1} \mathrm{H}-\mathrm{NMR}$ based assay developed herein. Methyl lactate without ${ }^{13} \mathrm{C}$ is formed from $\left[1-{ }^{13} \mathrm{C}\right]$ xylose upon direct retro-aldol cleavage (between $\mathrm{C} 2$ and $\mathrm{C} 3$ ) of the aldose, generating a C3-fragment without ${ }^{13} \mathrm{C}$. Methyl lactate with ${ }^{13} \mathrm{C}$ at the $\mathrm{C} 1$ or $\mathrm{C} 3$ position is formed from the ketose form after a 1,2-HS in the substrate. Methyl lactate with ${ }^{13} \mathrm{C}$ labelling of the $\mathrm{C} 2$ position results from an initial 1,2-CS leading to $\left[2-{ }^{13} \mathrm{C}\right]$ pentose, followed by aldose-to-ketose isomerization and retro-aldol cleavage of the $\left[2-{ }^{13} \mathrm{C}\right]$ ketopentose to a $\mathrm{C} 3$ fragment with ${ }^{13} \mathrm{C}$ still at the $\mathrm{C} 2$ position (Fig. 5).

Comparison of isotope distributions in the presence and in the absence of added $\mathrm{K}_{2} \mathrm{CO}_{3}$ shows that methyl lactate formed at conditions that are relevant for prospective chemocatalytic processes $\left(160^{\circ} \mathrm{C}\right)$ results from an aldol cleavage of the aldose form of $\left[1-{ }^{13} \mathrm{C}\right]$ xylose for $22 \%$ of substrate molecules in the absence of added alkali ions: $22 \%$ of methyl lactate does not contain ${ }^{13} \mathrm{C}$. Of the remaining $78 \%$ substrate molecules reacting through a ketose intermediate, $7 \%$ reacted from the $\left[2-{ }^{13} \mathrm{C}\right]$ ketose form upon a $1,2-\mathrm{CS}$ to for $\left[2-{ }^{13} \mathrm{C}\right]$ methyl lactate. The remaining $71 \%$ substrate reacted through a $\left[1-{ }^{13} \mathrm{C}\right]$ ketopentose to $\left[1-{ }^{13} \mathrm{C}\right]$ methyl lactate or $\left[3-{ }^{13} \mathrm{C}\right]$ methyl lactate.

In the presence of $0.5 \mathrm{mM}$ added $\mathrm{K}_{2} \mathrm{CO}_{3}$, the fraction of substrate that was converted through an aldol cleavage of [1${ }^{13} \mathrm{C}$ ] xylose increased from $22 \%$ to $31 \%$. Most significantly, the 


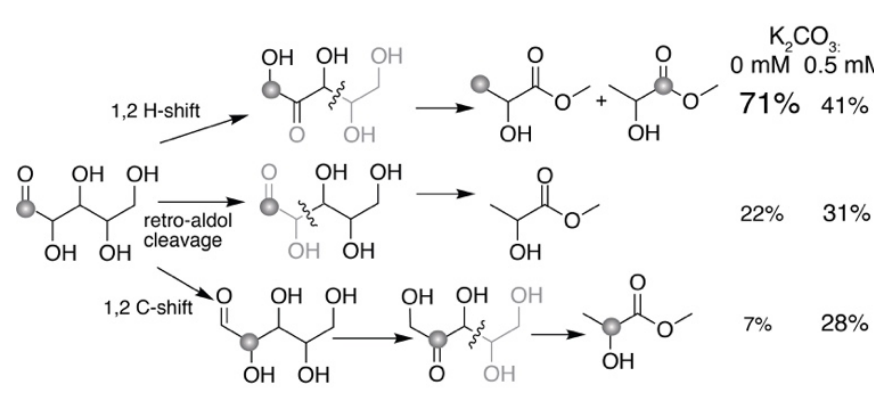

Fig. 5. Formation of different isotopologues of methyl lactate from $\left[1-{ }^{13} \mathrm{C}\right]$ xylose by different initial reactions of the substrate at the catalyst, in the absence and in the presence of added $\mathrm{K}_{2} \mathrm{CO}_{3}$.

fraction reacting through a $\left[2-{ }^{13} \mathrm{C}\right]$ ketopentose upon a $1,2-\mathrm{CS}$ increased from $7 \%$ to $28 \%$, while the fraction reacting through a $\left[1-{ }^{13} \mathrm{C}\right]$ ketopentose decreased from $71 \%$ to $41 \%$. These distributions showed that the propensity of reaction flux through $1,2-\mathrm{CS}$ increases relative to $1,2-\mathrm{HS}$ at $160^{\circ} \mathrm{C}$, similar to previous observations in $\mathrm{Sn}$-Beta catalysed isomerization reactions. ${ }^{7,} 32$ In addition, retro-aldol cleavage of the substrate in the aldosel form is enhanced. This observation is consistent with a lower activity for competing aldose-to-ketose isomerization (1,2-HS) and higher activity for C-C breaking reactions in the presence of added alkali ions. Despite these changes in reaction preference in the presence of $0.5 \mathrm{mM}$ $\mathrm{K}_{2} \mathrm{CO}_{3}$, initial 1,2-HS at $\mathrm{Sn}$-Beta active sites still accounts for $41 \%$ of substrate influx into the methyl lactate pathway at $160{ }^{\circ} \mathrm{C}$ (Fig. 5).

\section{Conclusions}

In conclusion, changing preferences for the initial conversion of carbohydrate were inferred under conditions that favour conversion to methyl lactate. The conclusions were afforded by (i) site specific isotope labelling, (ii) the use of a C5 substrate leading to asymmetric aldol cleavage and (iii) a novel analytical approach permitting the distinction of all isotopic forms of methyl lactate. This approach combines the reduction of carboxylic ester groups and ${ }^{1} \mathrm{H}$-based detection, and can notably be conducted using standard low-to-medium field NMR instrumentation. Isotope distributions could be measured within 10 minutes on a $400 \mathrm{MHz}$ NMR instrument, if nonuniform sampling was employed in the indirect dimension (Fig. S2, ESI). Overall, these results encourage the use of indirect detection schemes and chemical introduction of hydrogen groups for probing isotope enriched positions with routine NMR instrumentation and methodology. The approach concomitantly provides high information content, quantitativeness and sensitivity, thus reducing the material demand for expensive substrates in isotope tracking studies of chemocatalytic pathways.

Financial support from the Innovation Fund Denmark (case number 5150-00023B) is gratefully acknowledged. All $800 \mathrm{MHz}$ NMR spectra were recorded on the spectrometer of the NMR Center DTU supported by the Villum Foundation.

\section{Conflicts of interest}

There are no conflicts to declare.

\section{References}

1. M. Choi, K. Na, J. Kim, Y. Sakamoto, O. Terasaki and R. Ryoo, Nature, 2009, 461, 246-249.

2. A. Corma, V. Fornes, S. B. Pergher, T. L. M. Maesen and J. G. Buglass, Nature, 1998, 396, 353-356.

3. P. A. Jacobs, M. Dusselier and B. F. Sels, Angew. Chem. Int. Ed., 2014, 53, 8621-8626.

4. A. Corma, Journal of Catalysis, 2003, 216, 298-312.

5. T. C. Keller, K. Desai, S. Mitchell and J. Pérez-Ramírez, ACS Catal., 2015, 5, 5388-5396.

6. Y. Ono, J. Catal., 2003, 216, 406-415.

$7 . \quad$ R. Bermejo-Deval, M. Orazov, R. Gounder, S.-J. Hwang and M. E. Davis, ACS Catal., 2014, 4, 2288-2297.

8. P. Kern, M. Klimczak, T. Heinzelmann, M. Lucas and P. Claus, Appl. Catal. B, 2010, 95, 48-56.

9. T. W. M. Fan and A. N. Lane, Prog. Nucl. Mag. Res. Sp. 2016, 92-93, 18-53.

$10 . \quad$ T. W. M. Fan, P. K. Lorkiewicz, K. Sellers, H. N. B. Moseley, R. M. Higashi and A. N. Lane, Pharmacol. Therapeut., 2012, 133, 366-391.

11. A. N. Lane and T. W. M. Fan, Metabolomics, 2007, 3, 7986.

12. I. A. Lewis, R. H. Karsten, M. E. Norton, M. Tonelli, W. M. Westler and J. L. Markley, Anal. Chem., 2010, 82, 45584563.

13. T. Szyperski, Eur. J. Biochem., 1995, 232, 433-448.

14. C. Yang, Q. Hua and K. Shimizu, Metab. Eng., 2002, 4, 202216.

15. P. R. Jensen and S. Meier, Analyst, 2016, 141, 823-826.

16. M. S. Holm, S. Saravanamurugan and E. Taarning, Science, 2010, 328, 602.

17. M. S. Holm, Y. J. Pagán-Torres, S. Saravanamurugan, A. Riisager, J. A. Dumesic and E. Taarning, Green Chem., 2012, 14, 702-706.

18. S. Tolborg, S. Meier, I. Sádaba, S. G. Elliot, S. K. Kristensen, S. Saravanamurugan, A. Riisager, P. Fristrup, T. Skrydstrup and E. Taarning, Green Chem., 2016, 18, 3360-3369.

19. R. De Clercq, M. Dusselier, C. Christiaens, J. Dijkmans, R. I. lacobescu, Y. Pontikes and B. F. Sels, ACS Catal. 2015, 5, 5803-5811.

20. R. De Clercq, M. Dusselier and B. F. Sels, Green Chem., 2017, 19, 5012-5040.

21. S. Tolborg, I. Sádaba, C. M. Osmundsen, P. Fristrup, M. S. Holm and E. Taarning, ChemSusChem, 2015, 8, 613-617.

22. S. G. Elliot, I. Tosi, S. Meier, J. S. Martinez-Espin, S. Tolborg and E. Taarning, Catal. Sci. Technol., 2019, 9, 4339-4346.

23. M. Boronat, P. Concepción, A. Corma, M. Renz and S. Valencia, Journal of Catalysis, 2005, 234, 111-118.

24. W. R. Gunther, V. K. Michaelis, M. A. Caporini, R. G. Griffin and Y. Román-Leshkov, J. Am. Chem. Soc., 2014, 136, 6219-6222.

25. S.-J. Hwang, R. Gounder, Y. Bhawe, M. Orazov, R. Bermejo-Deval and M. E. Davis, Top. Catal., 2015, 58, 435440.

26. Y. G. Kolyagin, A. V. Yakimov, S. Tolborg, P. N. R. Vennestrøm and I. I. Ivanova, J. Phys. Chem. Lett., 2016, 7, 1249-1253. 
27. S. Roy, K. Bakhmutsky, E. Mahmoud, R. F. Lobo and R. J. Gorte, ACS Catal., 2013, 3, 573-580.

28. V. L. Sushkevich, I. I. Ivanova and A. V. Yakimov, J. Phys. Chem. C, 2017, 121, 11437-11447.

29. P. Wolf, M. Valla, F. Núñez-Zarur, A. Comas-Vives, A. J. Rossini, C. Firth, H. Kallas, A. Lesage, L. Emsley, C. Copéret and I. Hermans, ACS Cata., 2016, 6, 4047-4063.

30. A. V. Yakimov, Y. G. Kolyagin, S. Tolborg, P. N. R. Vennestrøm and I. I. Ivanova, J. Phys. Chem. C, 2016, 120, 28083-28092.

31. C. Jang, L. Chen and J. D. Rabinowitz, Cell, 2018, 173, 822837.

32. S. G. Elliot, E. Taarning, R. Madsen and S. Meier, ChemCatChem, 2018, 10, 1414-1419.

33. H. C. Brown and B. C. S. Rao, J. Am. Chem. Soc., 1956, 78, 5694-5695.

34. T. Yamakawa, M. Masaki and H. Nohira, B. Chem. Soc. Jpn, 1991, 64, 2730-2734.

35. P. C. P, E. Joseph, A. A, N. D. S, I. Ibnusaud, J. Raskatov and B. Singaram, J. Org. Chem., 2018, 83, 1431-1440.

36. T. W. M. Fan and A. N. Lane, Prog. Nucl. Mag. Res. Sp., 2008, 52, 69-117.

37. T. W. M. Fan and A. N. Lane, J. Biomol. NMR, 2011, 49, 267-280.

38. S. G. Elliot, I. Tosi, A. Riisager, E. Taarning and S. Meier, Topics in Catalysis, 2019, 62, 590-598.

39. J. R. Christianson, S. Caratzoulas and D. G. Vlachos, ACS Catal., 2015, 5, 5256-5263.

TOC figure 